\title{
Characteristics of subsurface wastewater infiltration systems fed with dissolved or particulate organic matter
}

\author{
J. Pan $\cdot$ L. Yu
}

Received: 30 March 2013/Revised: 8 June 2013/Accepted: 22 October 2013/Published online: 5 November 2013

(C) Islamic Azad University (IAU) 2013

\begin{abstract}
The influent type of organic matter (dissolved or particulate) on the characteristics of two subsurface wastewater infiltration systems (SWISs) was investigated. One of the SWISs was fed with dissolved organic matter (glucose, assumed to be readily biodegradable) and the other with particulate organic matter (starch, assumed to be slowly biodegradable). Results showed that both biofilm growth and particle accumulation in substrate could reduce the effective porosity and infiltration rate of SWIS, especially for the high organic matter concentration wastewater. The reduction in effective porosity and infiltration rate was primarily caused by organic particle accumulation. The contribution of the accumulated organic particle to the process of clogging was greater than that of biofilm growth and the clogging mainly occurred in the upper layer in starch-fed systems. The SWISs fed with glucose were not clogged till the end of experiments. The hydraulic retention time (HRT) increased with time in start-up period and was almost invariable after mature in glucose-fed systems; in starch-fed systems, clogging of substrate prolonged the HRT. The two identical experimental SWISs were almost equal efficiencies for the removal of chemical oxygen demand (COD). The removal efficiencies of COD were not influenced by clogging under the experimental conditions. Ammonia $\mathrm{N}$ removal efficiency was higher in glucose-fed systems than that in starch-fed systems.
\end{abstract}

\footnotetext{
J. Pan $(\bowtie)$

College of Chemical and Life Science, Shenyang Normal University, 253, Huanghe Street, Shenyang 110034, China e-mail: crystalpan78@126.com

L. Yu

Experimental Centre, Shenyang Normal University, 253,

Huanghe Street, Shenyang 110034, China

e-mail: 13137025@qq.com
}

Keywords Subsurface wastewater infiltration system . Glucose $\cdot$ Starch $\cdot$ Hydraulic retention time $\cdot$ Clogging

\section{Introduction}

Subsurface wastewater infiltration system (SWIS) is an effective way to treat wastewater according to integrated mechanisms of chemical, physical and biological reactions as it passes through the unsaturated soil in infiltration system (USEPA 2002; Zhang et al. 2005; Wang et al. 2010). Compared to the conventional activated sludge and biofilm processes, this system has better performance in organic substance and phosphorus removal, lower construction and operational costs, and easier management and maintenance (Yamaguchi et al. 1996; USEPA 2002; Li et al. 2012).

SWIS is a process suitable for decentralized domestic wastewater treatment in villages, small towns or scattered residential areas. Wastewater contains complex mixtures of organic matter of different size and types, from dissolved to particulate, and from readily biodegradable to inert constituents (Kadlec 2003). Long-term experience in conventional biological wastewater processes (such as activated sludge and wetland) has demonstrated that the efficiency can be highly dependent on the particle-size distribution function in the influent wastewater (Levine et al. 1991; Puigagut et al. 2007). Particulate organic biodegradable substrates (as well as high molecular weight dissolved and colloidal constituents) must undergo cell external hydrolysis before they are available for biodegradation. This hydrolysis process can be one of the most limiting steps during the removal of organic matter either under anaerobic, anoxic and aerobic conditions (Ubukata 
1997; Sanders et al. 2000). Thus, it is possible that this distribution function also affects the performance of other wastewater biological systems such as SWIS.

There is current no experimental information available on the comparative effect of particulate and dissolved organic matters on the characteristics of SWIS, such as removal efficiency and characteristics of substrate. Several reports, nevertheless, have recently discussed in a theoretical manner the possible effect of particle-size distribution. For example, Tchobanoglous (2003) pointed out the importance of organic matter size distribution as a design criterion and reviewed pretreatment systems for reducing particulate matters and therefore for modifying the size distribution function. Hua et al. (2010) investigated the effects of particulate solids distribution and their accumulation in the substrate of vertical-flow constructed wetlands with different gravel sizes and claimed that the SS whose particle size was less than $100 \mu \mathrm{m}$ were absorbed firstly, and then, the bigger size of the particles was intercepted and was accumulated at the end. Caselles-Osorio and García (2006) evaluated the performance of experimental horizontal subsurface flow constructed wetlands fed with dissolved or particulate organic matter and demonstrated that the removal of ammonia $\mathrm{N}$ was slightly higher in the glucose-fed wetland than starch-fed wetland.

In the present study, two pilot subsurface wastewater infiltration systems filled with the same mixed substrate and operated under the same conditions were constructed in the laboratory of Shenyang Normal University, but one fed with starch (as a slowly biodegradable particulate organic matter) and the other with glucose (as a readily biodegradable dissolved organic matter). The experiments were conducted from May 2010 to October 2010. The purposes in this study were as follows: (1) to investigate the different development of clogging processes caused by organic particle accumulation and biofilm growth, (2) to analyze the cause of the different clogging process and (3) to study the effect of clogging on removal efficiency and characteristics of substrate.

\section{Materials and methods}

\section{Pilot system setup and operation}

A schematic representation of the columns used for SWIS is shown in Fig. 1. The column was made from clear plexiglass $(120 \mathrm{~cm}$ in length and $50 \mathrm{~cm}$ internal diameter). Sampling ports were installed at $50 \mathrm{~cm}$ (upper layer), $80 \mathrm{~cm}$ (middle layer) and $110 \mathrm{~cm}$ (bottom layer) from the top of the SWIS to test effective porosity, infiltration rate, organic matter content and the biomass of substrate. The

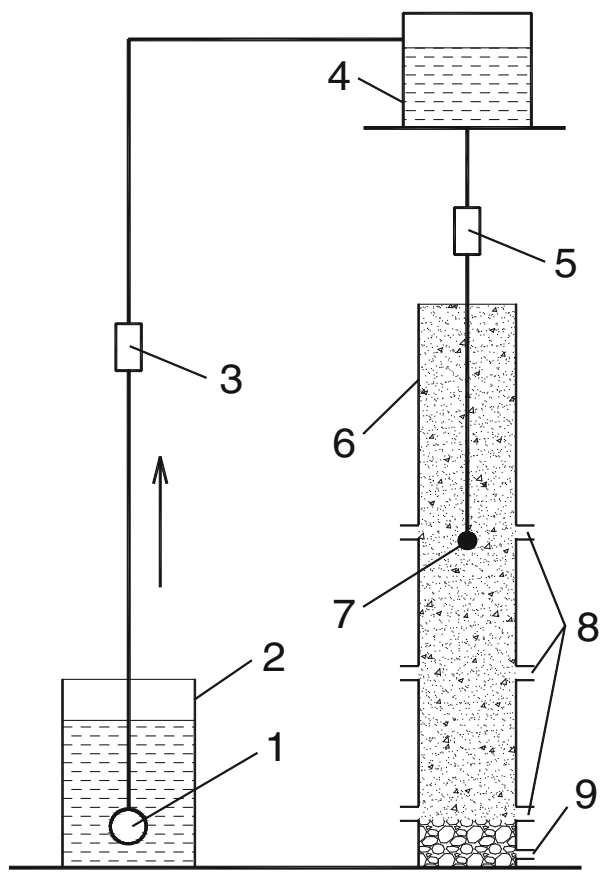

Fig. 1 Schematic diagram of the SWIS.(1) submerged pump; (2) synthetic wastewater tank; (3) control valve; (4) high-level feed tank; (5) flow meter; (6) infiltration system body; (7) inlet; (8) sampling ports; (9) outlet

$10 \mathrm{~cm}$ of deep gravel (10-20 mm, diameter) was prepared at the bottom to support infiltration system and evenly distribute the treated water. Synthetic wastewater was continuously fed into each SWIS from a feed tank through a rubber hose with flow rate control valves, and the synthetic influent was daily prepared. The feed tank was placed in a higher position so that influent could flow automatically into the SWIS. Synthetic wastewater inlet was installed in advance at the depth of $50 \mathrm{~cm}$ below the surface. The treated water was collected through collecting pipe at the bottom of the column near the outlet. Each infiltration system filled with the same substrate made of $50 \%$ brown soil and cinder at a weight percentage of $50 \%$. Cinder is an inorganic waste produced in the process of anthracite combustion, mainly composed of $\mathrm{SiO}_{2}$ and $\mathrm{Al}_{2} \mathrm{O}_{3}$.

The brown soil was collected from the top $20 \mathrm{~cm}$ from Shenyang Ecological Station. The coal slag was purchased from a local market in Shenyang, $4-8 \mathrm{~mm}$ in diameter. The mixed substrate contained total organics $20.4 \pm 0.6 \mathrm{~g} / \mathrm{kg}$, total nitrogen $0.3 \pm 0.08 \mathrm{~g} / \mathrm{kg}$, total phosphorus $0.2 \pm 0.1 \mathrm{~g} / \mathrm{kg}$ and $\mathrm{pH} 6.5$.

The indoor temperature was over $15{ }^{\circ} \mathrm{C}$ during the experiments. Two types of organic synthetic influents prepared by tap water except organic carbon source were used in this study. One organic carbon source was glucose, and the other was starch. Major nutrients were supplied by adding $\mathrm{NH}_{4} \mathrm{Cl}$ and $\mathrm{K}_{2} \mathrm{HPO}_{4}$ to the influents. 
Glucose was used to simulate the presence of soluble organic matter and investigate the clogging process caused by the biofilm growth in three columns. Starch used in the experiment was amylopectin, as a kind of organic particulate substrate, which must undergo cell external hydrolysis before it is available for biodegradation (Caselles-Osorio and García 2006). Therefore, the other three starch-fed SWISs were used to investigate the development process of clogging synthetically caused by biofilm growth and particle accumulation, especially for the latter.

In this study, the hydraulic loading was kept constant at $0.4 \mathrm{~m}^{3} /\left(\mathrm{m}^{2}\right.$ day $)$, and each cycle of the operation included a flooding period of $24 \mathrm{~h}$, a drying period of $24 \mathrm{~h}$. Organic loading was an important factor causing clogging of infiltration systems (Zhao et al. 2009). In order to investigate the effect of organic loading on clogging, low, middle and high organic matter concentration were constructed in this study. The water quality of the synthetic wastewater was listed in Table 1.

\section{Sampling and analyzing}

Sampling was conducted in the flooding period from May 2010 to October 2010. Infiltration rate, effective porosity, hydraulic retention time and water quality were measured every 7 cycles of the operation. OM content and the amount of bacterial biomass were measured every 14 cycles of the operation.

\section{Infiltration rate measurement}

Infiltration rate measurement was based on the variable water head method of Standard for Soil Test Method (GB/ T50123-1999) with TST-55 infiltrometer (Nanjing Ningxin Soil Instrument Factory, China). The value of infiltration rate $\mathrm{K}(\mathrm{cm} / \mathrm{s})$ could be calculated through the following equation (Eq. 1).
$K=2.3 \frac{a L}{A t} \log \frac{h_{1}}{h_{2}}$

where $a\left(\mathrm{~cm}^{2}\right)$ is surface area of variable water head pipe, $t(\mathrm{~s})$ is the change in time during the head drop, $L(\mathrm{~cm})$ is the length of the filter, $h_{1}(\mathrm{~cm})$ is the initial water head, $h_{2}(\mathrm{~cm})$ is the final water head and $A$ is surface area of the substrate. In this study, $a$ is $1 \mathrm{~cm}^{2}, L$ is $4 \mathrm{~cm}$ and $A$ is $30 \mathrm{~cm}^{2}$.

\section{Effective porosity measurement}

The effective porosity was tested through the balance of the water saturation and venting volume of the substrate. It can be expressed as a ratio of the values of drainage volume divided by the total volume before filling with substrate (Hua et al. 2010).

\section{OM content accumulated in substrate}

The loss on ignition (LOI) method (Tanner and Sukias 1995) was used to calculate the organic matter content accumulated in substrate. Samples of each layer were taken with sampler and mixed evenly. Some of the above mixed substrates were dried to constant weight in a forced air oven at $80{ }^{\circ} \mathrm{C}$ and then were burnt at $550{ }^{\circ} \mathrm{C}$ for $4 \mathrm{~h}$. The weight difference before and after burning was estimated as OM content of substrate.

\section{The amount of bacterial biomass in substrate}

Total bacterial biomass of substrate has previously been used to study biological clogging (Stéphanie et al. 2000; Liu et al. 2003). The biofilm microbial biomass was evaluated using a fatty acid methyl ester method (MIS Operating Manual 1991). This method provided an unbiased view of the complex microbial communities and viable biomass found in environmental samples such as soils (Ratcliff et al. 2006) and sediments (Ringelber et al. 1997). The fatty acids of the bacteria present in the sample were extracted, converted to

Table 1 Water quality of the synthetic organic influent

\begin{tabular}{|c|c|c|c|}
\hline Concentration & COD (mg/L) & Ammonia N (mg/L) & $\mathrm{TP}(\mathrm{mg} / \mathrm{L})$ \\
\hline \multicolumn{4}{|c|}{ Glucose influent } \\
\hline Low & $38.45-44.03(40.26)$ & $31.37-42.83(36.44)$ & $3.78-6.25(4.68)$ \\
\hline Middle & $168.36-182.74(177.52)$ & $33.21-40.86(35.87)$ & $3.64-6.08(4.16)$ \\
\hline High & $367.21-374.73(370.52)$ & $32.58-41.06(36.37)$ & $4.02-6.85(4.56)$ \\
\hline \multicolumn{4}{|l|}{ Starch influent } \\
\hline Low & $37.16-45.53(41.47)$ & $30.38-41.56(34.09)$ & $3.92-6.37(4.35)$ \\
\hline Middle & $169.87-178.58(173.62)$ & $31.87-40.67(35.06)$ & $3.88-6.02(4.28)$ \\
\hline High & $368.81-376.80(372.86)$ & $32.64-40.38(36.47)$ & $4.13-5.94(4.96)$ \\
\hline
\end{tabular}

Data in parentheses are mean values 
fatty acid methyl esters and directly correlated to dry weight of bacterial biomass and total cell numbers (Haack et al. 1994). The method was tested by adding a known amount of bacterial biomass to different amounts of substrate. The recovery rates of fatty acids were then converted and correlated back to bacterial biomass concentration.

\section{Hydraulic retention time}

Tracer tests were carried out in SWISs using sodium chloride $(\mathrm{NaCl})$, the concentration of which can be easily monitored by electrical conductivity sensors. In each test, the tracer was added to the water of only one feeding sequence. The tracer content and the flow rate at the outlet of the SWISs were recorded each minute. This monitoring allowed to determine the detention time distribution (DTD), DTD $=\mathrm{E}(\mathrm{t})$, and the mean hydraulic retention time (HRT) (Torrens et al. 2009). The HRT is determined as follows:
$\mathrm{HRT}=\int_{0}^{\infty} t \cdot E(t) \cdot \mathrm{d} t$

Analysis methods for water quality

Influent and effluent samples were analyzed immediately for ammonia $\mathrm{N}$ and chemical oxygen demand (COD) using Chinese EPA standard methods (2002).

\section{Results and discussion}

Infiltration rate of each layer in two SWISs

Figure 2 shows the changes in infiltration rate with different organic matter concentration overtime in starch-fed and glucose-fed systems. At beginning, the infiltration rate
Fig. 2 Infiltration rate of each layer in glucose-fed and starchfed systems
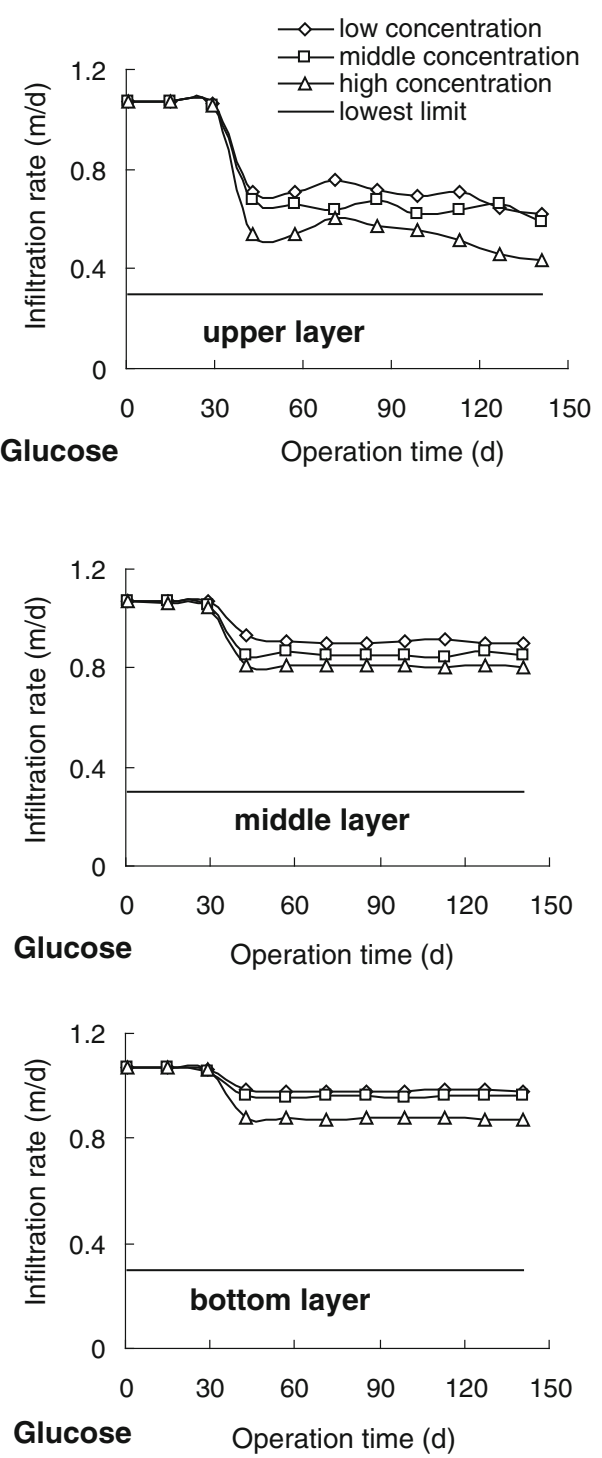
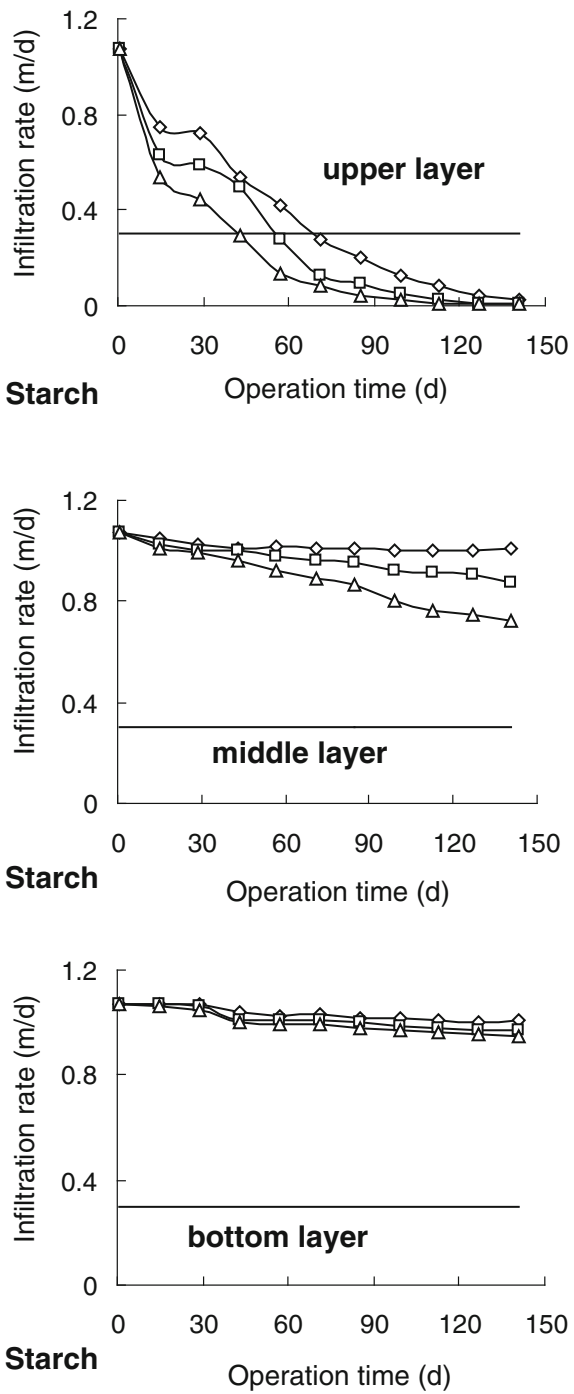
of each layer did not change significantly and the rapid decline of the infiltration rate was observed during the operation time of around 43 days in glucose-fed systems. However, the infiltration rate of upper layers decreased significantly at the incipient stage of operation in starch-fed systems. In previous study, Pan (2009) concluded that the lowest limit infiltration rate $\left(K_{L}\right)$ was around $0.3 \mathrm{~m} / \mathrm{d}$ and the SWIS would occur clogging when infiltration rate was lower than $K_{L}$. The infiltration rates of upper layers in all starch-fed systems with different COD concentrations decreased to $K_{L}$ within 71 days. Organic matter concentration showed some effects on the infiltration rate of SWIS. The infiltration rate was lower for the systems fed with higher concentration influents. For the starch-fed system with COD concentration of $372.86 \mathrm{mg} / \mathrm{L}$, infiltration rate of upper layer decreased to $K_{L}$ after running for
43 days while the reaching time was prolonged to 71 days when the organic concentration was $41.47 \mathrm{mg} / \mathrm{L}$. However, none of the infiltration rate of each layer in glucose-fed systems dropped to $K_{L}$ after running for 141 days. Suliman et al. (2006) considered that the effect of biological growth on infiltration rate was negligible. Zhao et al. (2009) suggested that except for organic loading, suspended solid content in the influent should also be paid attention in clogging, especially for the wastewater containing a large amount of particles.

Effective porosity of each layer in two SWISs

Both biofilm growth and suspended solid accumulation could occupy the pore space and then reduce the pore size of the SWIS. Figure 3 shows the changes in
Fig. 3 Effective porosity of each layer in glucose-fed and starch-fed systems
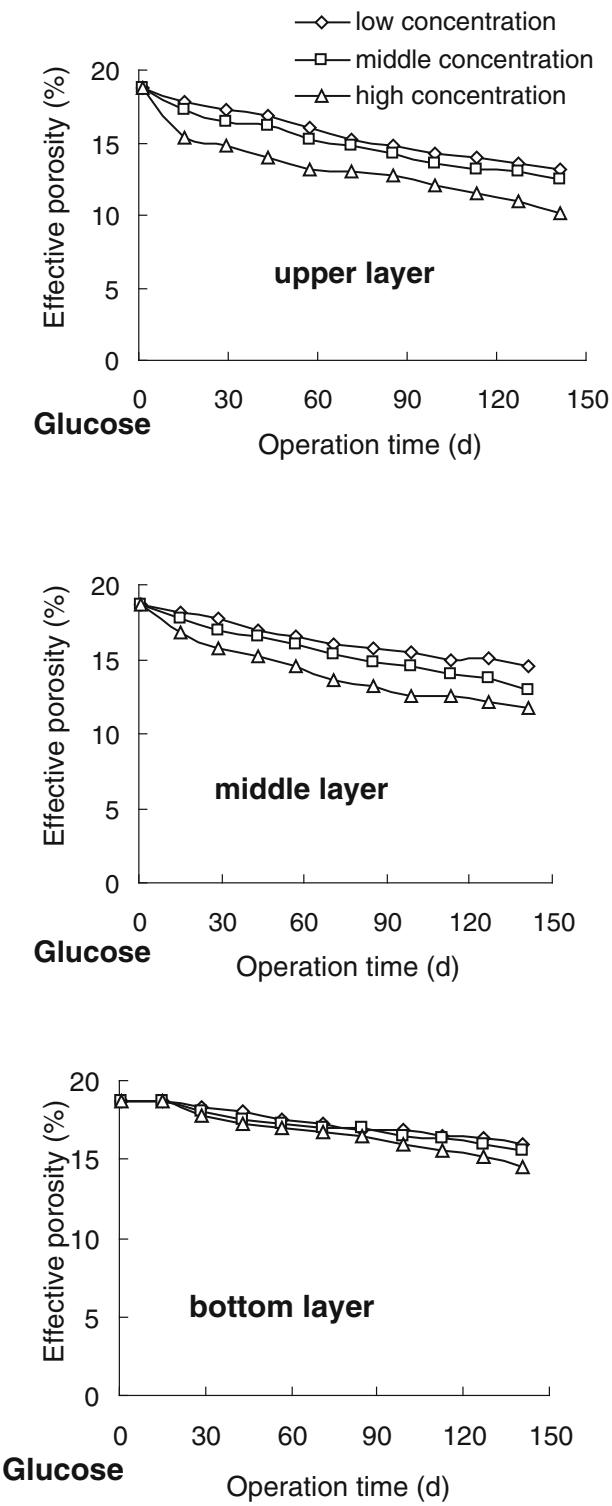
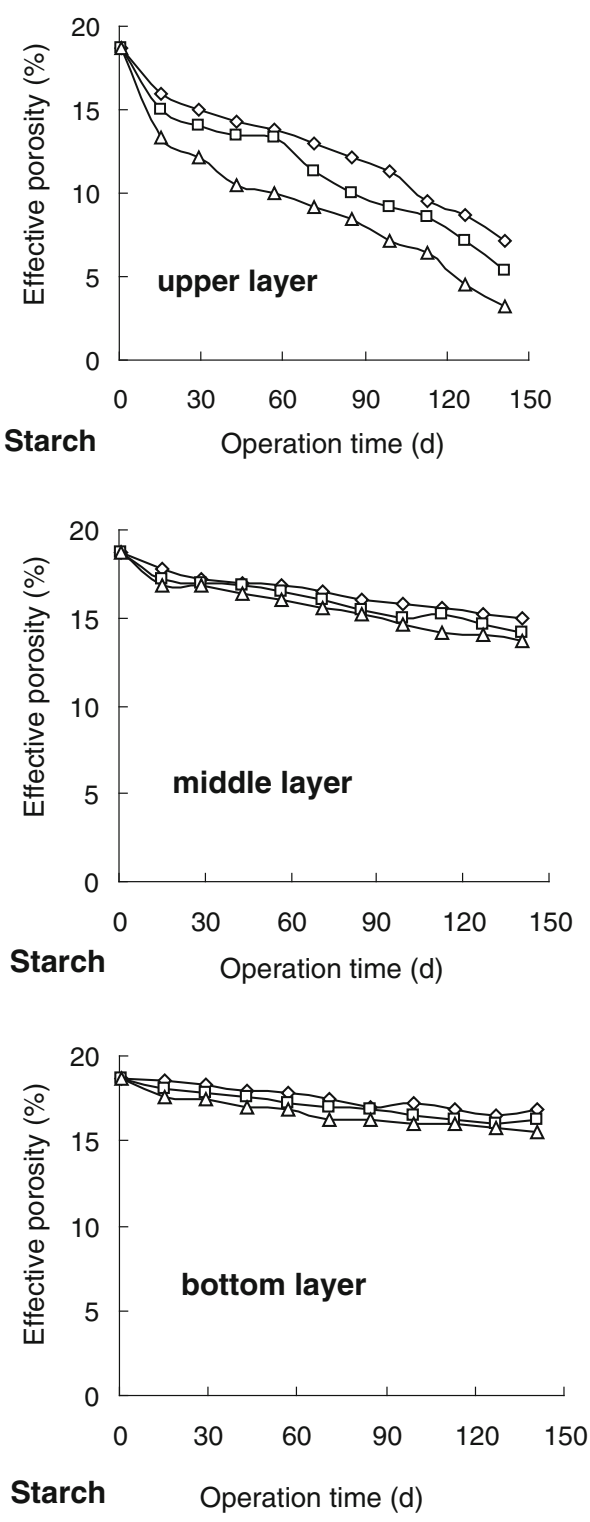
effective porosity for each layer in glucose-fed and starch-fed systems. It can be found that the reduction in effective porosity of the upper and middle layer was significant and that of the bottom was slight in glucosefed systems. This result can be explained that the nutrient and dissolved oxygen levels were higher in upper and middle layer, which was in favor of the bacterial cells adhere or grow there. The COD concentration had a significant influence on the effective porosity of glucose-fed systems. For instance, at the end of experiments, the effective porosity of upper layer was 13.2 and $10.1 \%$ with the COD concentration of 40.26 and $370.52 \mathrm{mg} / \mathrm{L}$, respectively. The reason was that biofilm could grow anywhere the organic influent flow across and then reduced the effective porosity there. For the starch-fed systems, however, the effective porosity only dropped rapidly in the upper layer, and it did not decrease basically with time in the middle and bottom layers. The reason was a large number of starch particles in influents adhered to substrate in upper layers, forming deposits and then accumulating in the pores thereby reducing the effective porosity. Starch particles in influents could hardly flow into middle and bottom layers with the occurrence of clogging.
Accumulated organic matter (OM) content of each layer in two SWISs

Figure 4 shows the accumulated OM content of each layer overtime in starch-fed and glucose-fed systems. The content in the upper layer was only slightly higher for the glucose-fed systems, whereas it was far higher for the starch-fed systems. In addition, the OM content increased with the increase in influent organic matter concentration. The main composition of accumulated OM in substrate was biofilm for the glucose-fed systems and detained starch particles for the upper layer of starch-fed systems. In glucose-fed systems, the nutrient and dissolved oxygen levels decreased along the depth of columns, which led to a decline of accumulated OM. In starch-fed systems, a large number of starch particles in influents adhered to substrate in upper layers, forming deposits and then accumulating in the pores, and starch particles in influents could hardly flow into middle and bottom layers.

Considering the infiltration rate along the depth of columns (Fig. 2), the infiltration rate was negatively related to the accumulated OM content, which confirmed that the accumulation of OM within substrate was one of the main reasons to the substrate clogging. This result was in accord
Fig. 4 Accumulated organic matter (OM) content of each layer in glucose-fed and starchfed systems
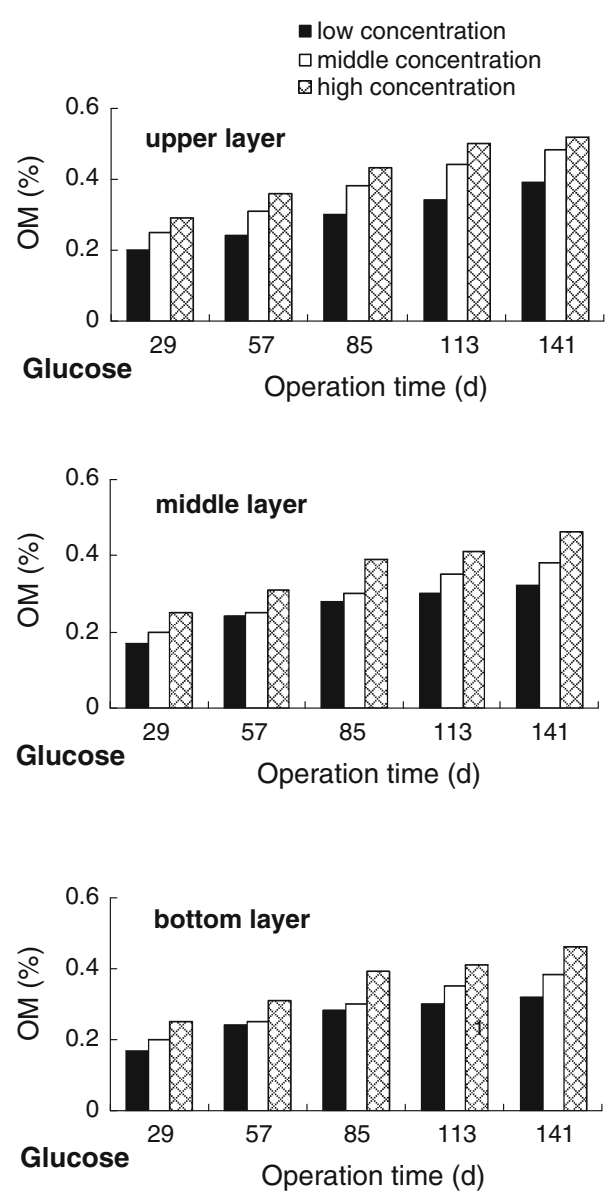
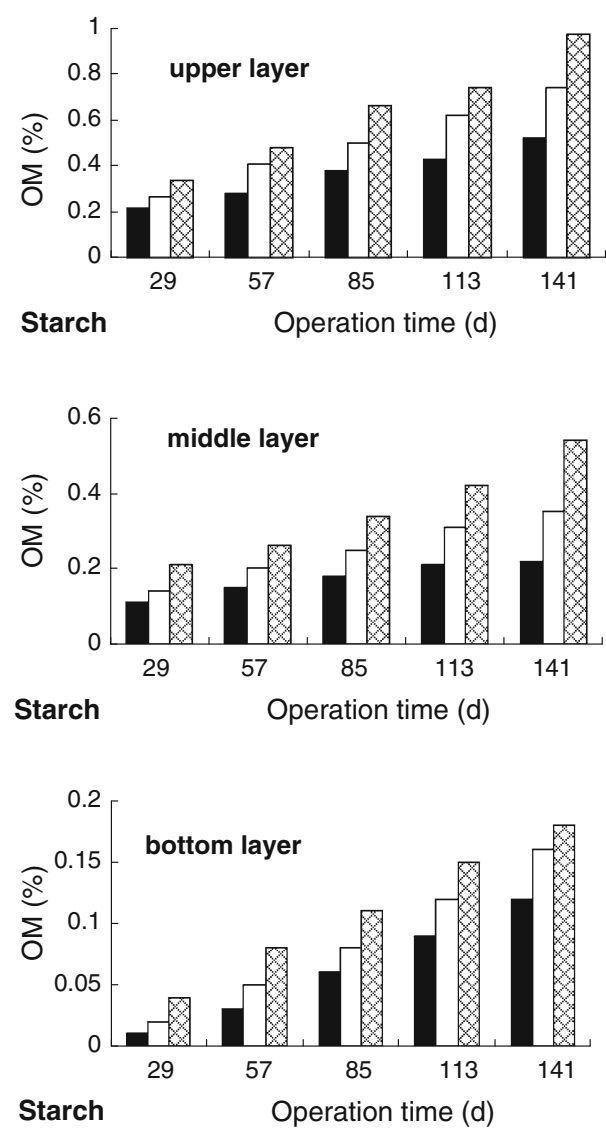
with the research conclusions by Zhan et al. (2003). Compared with the infiltration rate of glucose-fed system under the condition of similar OM content, the reduction in clogged layer in starch-fed system was greater. It can conclude that the influence of biofilm growth on infiltration rate was not as significant as that of starch particles, which is consistent with previous research by Suliman et al. (2006).

Considering the effective porosity along the depth of columns (Fig. 3), the accumulated OM content has some effects on effective porosity. For the starch-fed and glucose-fed systems, the effective porosity decreased with the increase in accumulated OM content. Compared with the effective porosity of glucose-fed systems under the condition of similar OM content and COD concentration, the reduction in clogged layer in starch-fed systems was greater. When the effective porosity was down to a certain degree, the starch particles could directly block the pores within substrate and led to rapid clogging phenomena.
The amount of bacterial biomass of each layer in two SWISs

The amount of bacterial biomass of each layer overtime in starch-fed and glucose-fed systems was quantified (Fig. 5). The results show that most of the biomass was produced in upper layer of each column because the nutrient and dissolved oxygen levels were highest. The amount of bacterial biomass increased with the increase in influent organic matter concentration. In glucose-fed systems, the amount of bacterial biomass increased from beginning to 57 days and was almost invariable in each layer after 57 days because start-up period of SWIS completed and biofilms matured after running for 41 days (Pan 2009). After running for 57 days, in starch-fed systems, the amount of bacterial biomass was almost invariable in upper layers, and nevertheless, in middle and bottom layers, the amount of bacterial biomass decreased. The reason is that the
Fig. 5 The amount of bacterial biomass of each layer in glucose-fed and starch-fed systems
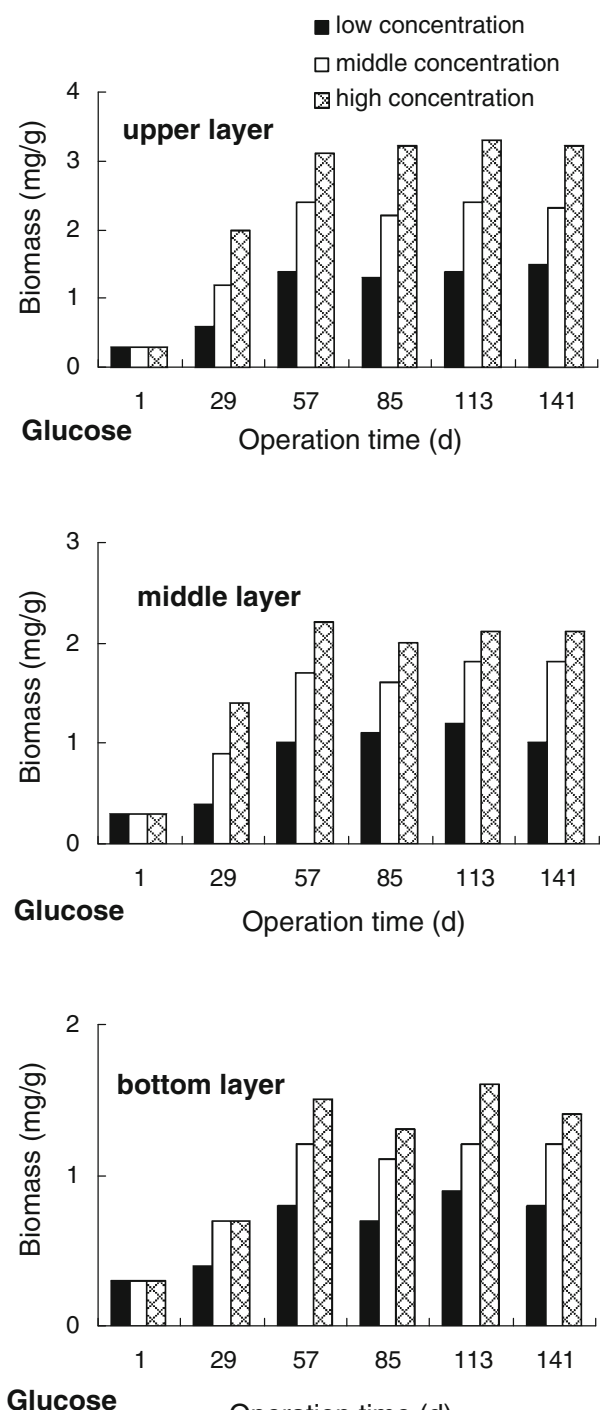

Operation time (d)
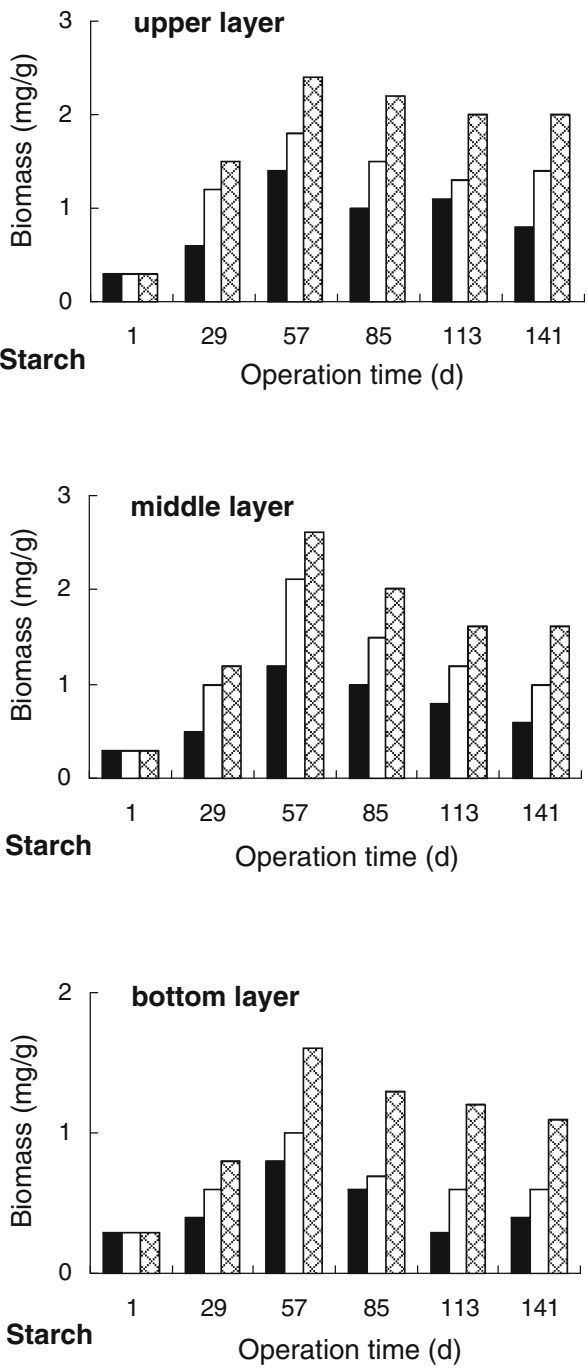
clogging occurred in upper layers, starch particles in influents could hardly flow into middle and bottom layers and bacteria could not obtain enough organic matter. The biomass in upper layers was less in starch-fed systems than that of glucose-fed systems, which was not in accordance with larger drop in the effective porosity (Fig. 3). Compared with the effective porosity of upper layer in glucosefed systems under the condition of similar amount of bacterial biomass and COD concentration, the reduction in clogged layer in starch-fed systems was greater. For instance, the effective porosity of upper layer was $17.2 \%$ in glucose-fed system and was $6.4 \%$ in starch-fed system under the condition of $2 \mathrm{mg} / \mathrm{g}$ bacterial biomass and high COD concentration, respectively. It can conclude that the reduction in effective porosity in upper (clogged) layers of starch-fed systems was primarily caused by organic particle accumulation. Many researches reported the growth of biofilm had minor effect on the reduction in effective porosity in filtration systems (Rodgers et al. 2007; Healy et al. 2007). Thullner et al. (2002) and Liu et al. (2003) thought biological growth formed continuous and uniform biofilm, which covered the wall of each pore leading to reduction in the pore diameter, and Caselles-Osorio et al. (2007) considered the particles interstitially accumulated in the pores. According to these previous studies, it can infer that the accumulated solids could reduce the pore spaces more rapidly than the biofilm growth could under the experimental conditions and the important contribution of the biofilm growth to clogging in practice is accelerating the occurrence of clogging.

\section{Hydraulic retention time of two SWISs}

The HRT of glucose-fed and starch-fed SWISs is shown in Fig. 6. The results show that HRT of glucose-fed systems was less than that of starch-fed systems. The HRT increased with the increase in influent organic matter concentration. The HRT increased with time before startup period and was almost invariable after 43 days in glucose-fed systems. In starch-fed systems, the HRT increased with time. For instance, the HRT increased from 13.4 to $20.1 \mathrm{~h}$ when the operation time increased from 29 to 141 days with COD concentration of $173.62 \mathrm{mg} / \mathrm{L}$. This phenomena already described by Tanner et al. (1998), who found a clear relationship between the hydraulic residence time and solids accumulation. The reason is effective porosity of starch-fed systems decreased due to detained starch particles in the upper layer, which decreased wastewater velocity, and the substrate of glucose-fed systems did not clog due to the balance between biological growth and bacterial decay after start-up period (Okabe et al. 1998).
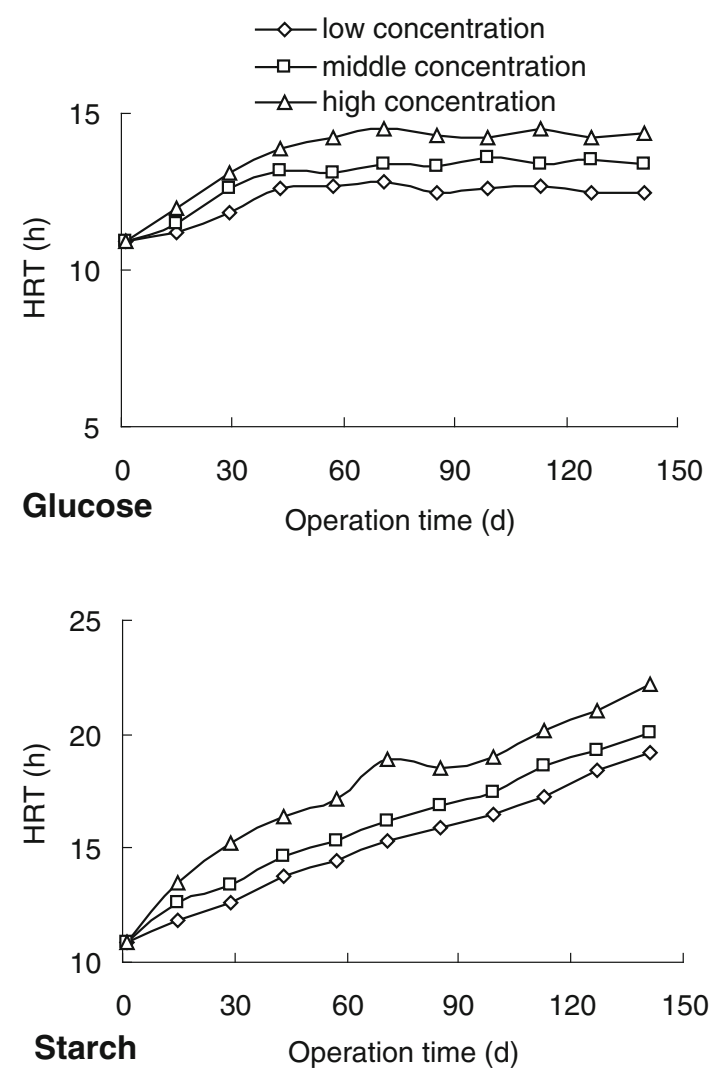

Fig. 6 Hydraulic retention time of glucose-fed and starch-fed systems

\section{Removal efficiency of two SWISs}

Figure 7 shows that the SWISs fed with different organic substrates (particulate slowly biodegradable and dissolved readily biodegradable) and operated with the same hydraulic loading yielded similar removal efficiencies of COD and reached eliminations of around $90 \%$ after mature. The results demonstrate that removal efficiencies of COD were not influenced by clogging in starch-fed systems and clogging of substrate only prolonged the HRT, which was testified in 3.5. It can conclude that SWIS was not sensitive to the type of organic matter in the influents if it is readily (like glucose) or slowly (like starch) biodegradable for the removal of COD under the experimental conditions.

Figure 8 shows that ammonia $\mathrm{N}$ removal efficiencies were significantly different in the SWISs fed with glucose and that fed with starch. In glucose-fed systems, the removal efficiencies of ammonia $\mathrm{N}$ increased from beginning to 57 days and were almost invariable after 57 days. This may be related to a higher degree of ammonia assimilation by heterotrophs in the SWISs fed with glucose because it is a readily biodegradable compound and favors the heterotrophic growth more in comparison with starch 

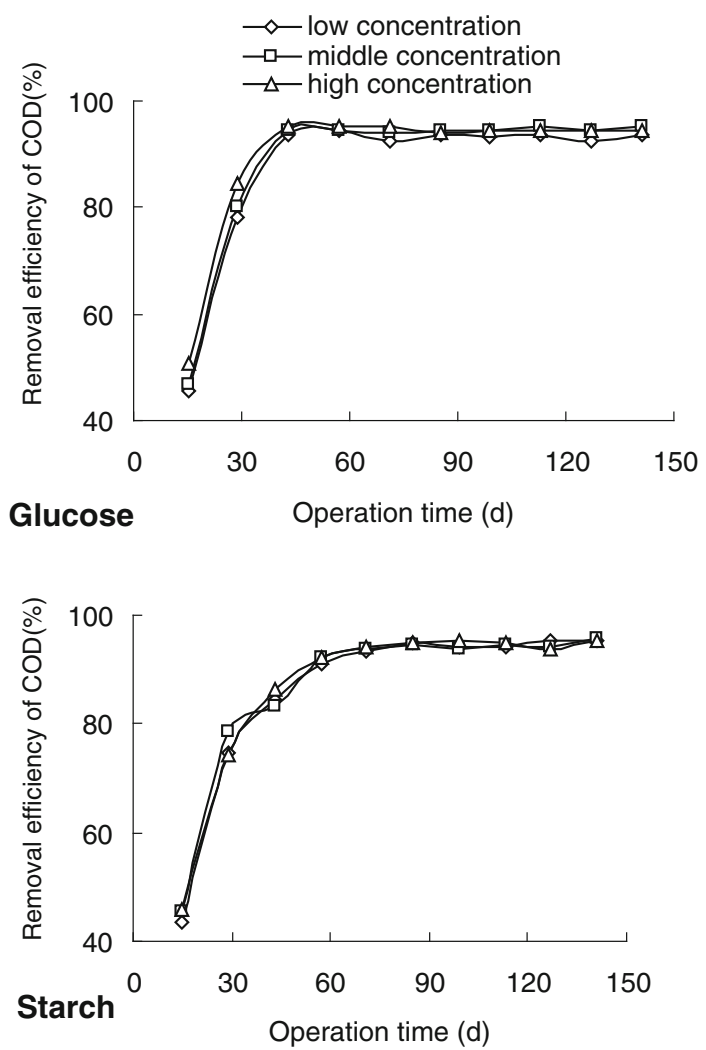

Fig. 7 Removal efficiency of COD in glucose-fed and starch-fed systems

(Caselles-Osorio and García 2006). In starch-fed systems, the removal efficiencies of ammonia $\mathrm{N}$ increased from beginning to 43 days and decreased after 43 days. The reason is that after 43 days most of starch was retained near the inlet, forming deposits and then accumulating in the pores, and heterotrophs could not obtain enough organic matter and ammonia $\mathrm{N}$.

\section{Conclusion}

Both biofilm growth and particle accumulation in substrate could reduce the effective porosity and infiltration rate of SWIS, especially for the high organic matter concentration wastewater. The reduction in effective porosity and infiltration rate was primarily caused by organic particle accumulation. The contribution of the accumulated organic particle to the process of clogging was greater than that of biofilm growth and the clogging mainly occurred in the upper layer in starch-fed systems. The SWISs fed with glucose were not clogged till the end of experiments. The important contribution of the biofilm growth to clogging in practice is accelerating the occurrence of clogging. The
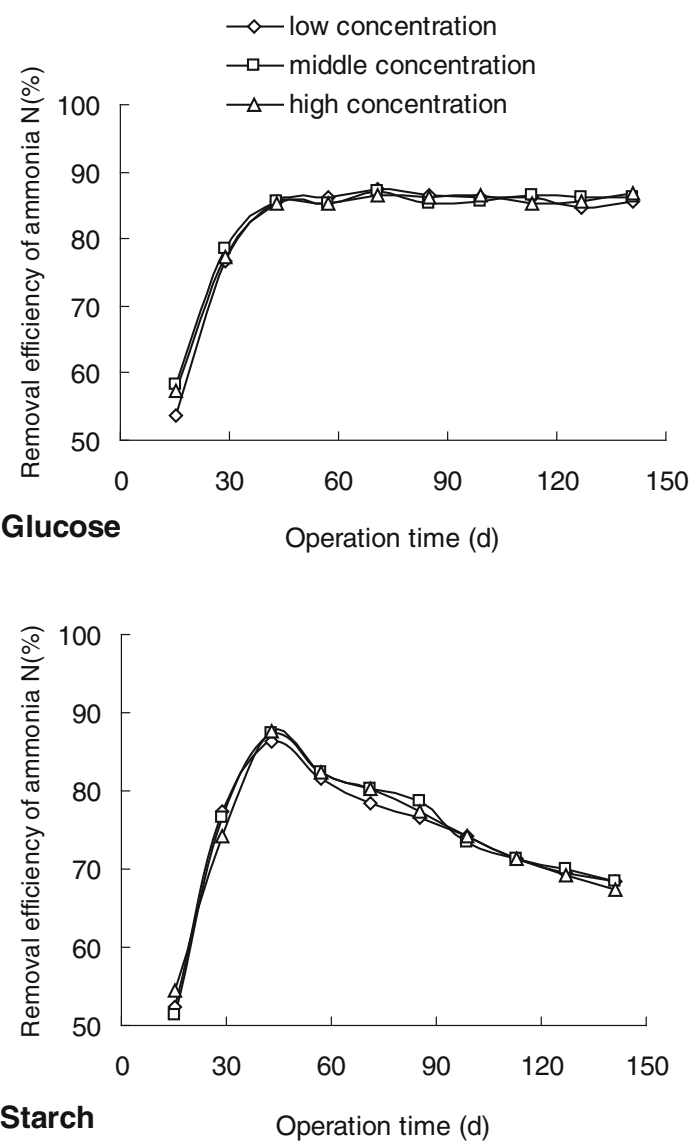

Fig. 8 Removal efficiency of ammonia $\mathrm{N}$ in glucose-fed and starchfed systems

HRT increased with time in start-up period and was almost invariable after mature in glucose-fed systems. In starchfed systems, clogging of substrate prolonged the HRT. The two identical experimental SWISs were almost equal efficiencies for the removal of COD with the same hydraulic loading. The removal efficiencies of COD were not influenced by clogging in starch-fed systems under the experimental conditions. The SWIS is not sensitive to the type of organic matter in the influents, whether it is readily (like glucose) or slowly (like starch) biodegradable, for the removal of COD. The removal efficiencies of ammonia $\mathrm{N}$ were higher in the glucose-fed systems than in starch-fed systems, which is probably related to a greater heterotrophic microbial growth in the former.

Acknowledgments This research is financially supported by the national natural science foundation of China (No.41001321), science and technology plan of Shenyang (No.F11-264-1-13), program for Liaoning excellent talents in university (No.LJQ2012093), ecology and environment research center director foundation of Shenyang normal university (EERC-Y-201301). 


\section{References}

Caselles-Osorio A, García J (2006) Performance of experimental horizontal subsurface flow constructed wetlands fed with dissolved or particulate organic matter. Water Res 40:3603-3611

Caselles-Osorio A, Puigagut J, Segú E et al (2007) Solids accumulation in six full-scale subsurface flow constructed wetlands. Water Res 41:1388-1398

EPA Chinese (2002) Methods for water and wastewater analysis, 4th edn. Environmental Science Publishing House of China, Beijing, pp 124-133

Haack SK, Garshow H, Odelson DA et al (1994) Accuracy, reproducibility, and interpretation of fatty acid methyl ester profiles of model bacterial communities. Appl Environ Microbiol 60:2483-2493

Healy MG, Rodgers M, Mulqueen J (2007) Treatment of dairy wastewater using constructed wetlands and intermittent sand filters. Bioresour Technol 98(12):2268-2281

Hua GF, Zhua W, Zhao LF et al (2010) Clogging pattern in verticalflow constructed wetlands: insight from a laboratory study. J Hazard Mater 180:668-674

Kadlec RH (2003) Effects of pollutant speciation in treatment wetlands design. Ecol Eng 20:1-16

Levine AD, Tchobanoglous G, Asano T (1991) Size distributions of particulate contaminants in wastewater and their impact on treatability. Water Res 25:911-922

Li HB, Li YH, Sun TH et al (2012) The use of a subsurface infiltration system in treating campus sewage under variable loading rates. Ecol Eng 38:105-109

Liu Q, Mancl K, Tuovinen OH (2003) Biomass accumulation and carbon utilization in layered sand filter biofilm systems receiving milk fat and detergent mixtures. Bioresour Technol 89:275-279

MIS Operating Manual (1991) MIDI Inc., Newark, Delaware, USA

Okabe S, Kuroda H, Watanabe Y (1998) Significance of biofilm structure on transport of inert particulates into biofilm. Water Sci Technol 38:163-170

Pan J (2009) Studies on microbiology character and intensified nitrogen removal technics in subsurface infiltration system. Northeastern University, Dissertation

Puigagut J, Salvadó H, García J (2007) Effect of soluble and particulate organic compounds on microfauna the community in subsurface flow constructed wetlands. Ecol Eng 29:280-286

Ratcliff AW, Busse MD, Shestak CJ (2006) Changes in microbial community structure following herbicide additions to forest soils. Appl Soil Ecol 34:114-124

Ringelber DB, Sutton S, White DC (1997) Biomass, bioactivity and biodiversity: microbial ecology of the deep subsurface: analysis of ester-linked phospholipids fatty acids. FEMS Microbiol Rev 20:371-377

Rodgers M, Mulqueen J, Healy MG (2007) Surface clogging in an intermittent stratified sand filter. Soil Sci Soc Am J 68:1827-1832
Sanders WTM, Geerink M, Zeeman G et al (2000) Anaerobic hydrolysis kinetics of particulate substrates. Water Sci Technol 41:17-24

Stéphanie RP, Santo R, Pascale S et al (2000) Interrelationships between biological, chemical, and physical processes as an analog to clogging in aquifer storage and recovery wells. Water Res 34:2110-2118

Suliman F, French HK, Haugen LE et al (2006) Change in flow and transport patterns in horizontal subsurface flow constructed wetlands as a result of biological growth. Ecol Eng 27:124-133

Tanner CC, Sukias JP (1995) Accumulation of organic solids in gravel-bed constructed wetlands. Water Sci Technol 32:229-239

Tanner CC, Sukias JPS, Upsdell MP (1998) Organic matter accumulation during maturation of gravel-bed constructed wetlands treating farm dairy wastewaters. Water Res 32:3046-3054

Tchobanoglous G (2003) Preliminary treatment in constructed wetlands. In: First international seminar on the use of aquatic macrophytes for wastewater treatment in constructed wetlands. Lisbon, Portugal, pp 13-33

Thullner M, Zeyer J, Kinzelbach W (2002) Influence of microbial growth on hydraulic properties of pore network. Transp Porous Med 49:99-122

Torrens A, Molle P, Boutin C et al (2009) Impact of design and operation variables on the performance of vertical-flow constructed wetlands and intermittent sand filters treating pond effluent. Water Res 43:1851-1858

Ubukata Y (1997) Kinetics of polymeric substrate (dextrine or peptone) removal by activated sludge: hydrolysis of polymers tomonomers in the rate-determining step. Water Sci Technol 36:159-167

USEPA (2002) Onsite wastewater treatment systems manual EPA/ 625/R-00/008. US Environmental Protection Agency, Washington, DC

Wang X, Sun TH, Li HB et al (2010) Nitrogen removal enhanced by shunt distributing wastewater in a subsurface wastewater infiltration system. Ecol Eng 36:1433-1438

Yamaguchi T, Moldrup P, Rolston SI et al (1996) Nitrification in porous media during rapid unsaturated water flow. Water Res 30:531-540

Zhan DH, Wu ZB, Xu GL (2003) Organic matter accumulation and substrate clogging in integrated vertical flow constructed wetland. China Environ Sci 23:457-461

Zhang J, Huang X, Liu CX et al (2005) Nitrogen removal enhanced by intermittent operation in a subsurface wastewater infiltration system. Ecol Eng 25:419-428

Zhao LF, Zhu W, Tong W (2009) Clogging processes caused by biofilm growth and organic particle accumulation in lab-scale vertical flow constructed wetlands. J Environ Sci 21:750-757 